\title{
Quality of leucaena, gliricidia, and pornunça silages with different old man saltbush levels
}

\author{
Qualidade de silagens de leucena, gliricídia e pornunça com \\ diferentes níveis de erva sal
}

\author{
Tadeu Vinhas Voltolini' ${ }^{1}$; Kaio Victor Justo Belem²; Gherman Garcia Leal de \\ Araújo $^{1}$; Salete Alves de Moraes ${ }^{1}$; Glayciane Costa Gois ${ }^{3 *}$; Fleming Sena Campos ${ }^{4}$
}

\section{Highlights:}

Ruminant food base in the Brazilian semiarid region is the Caatinga vegetation.

Silages can contribute to reducing food deficiency in the dry season.

Leucaena, pornunça, and gliricidia are used as food strategy in the semiarid.

Old man saltbush can improve fermentation patterns of silages.

\begin{abstract}
This study aimed to evaluate the quality of leucaena, gliricidia, and pornunça silages with different levels of old man saltbush inclusion in their composition. A completely randomized design was used with five levels of old man saltbush (Atriplex nummularia) inclusion $(0,25,50,75$, and $100 \%)$ in leucaena (Leucaena leucocephala), gliricidia (Gliricidia sepium), and pornunça (Manihot sp.) silages, with 5 replications per treatment, totaling 75 experimental mini-silos maintained in a covered shed and free of opportunistic animals. Silos were opened after 100 days of ensilage, and the silage of the first $15 \mathrm{~cm}$ of their ends was discarded. The remaining material was homogenized and sampled for determining the bromatological composition, in vitro digestibility, and fermentation profile. Old man saltbush inclusion levels in leucaena silages promoted a negative linear effect for dry matter, organic matter, crude protein, ethereal extract, $\mathrm{pH}$, and ammoniacal nitrogen, while a positive linear effect was found for mineral matter, in vitro dry matter digestibility, total carbohydrates, non-fibrous carbohydrates, and propionic acid $(\mathrm{P}<0.05)$. This silage also had a quadratic effect for lactic acid. Gliricidia silages showed a positive linear behavior for dry matter, mineral matter, and total carbohydrates, whereas organic matter, crude protein, and ethereal extract presented a negative linear behavior $(\mathrm{P}<0.05)$. The contents of organic lactic, acetic, and propionic acids showed a quadratic effect for gliricidia silage as old man saltbush levels increased $(\mathrm{P}<0.05)$. Regarding pornunça silage, dry matter, mineral matter, total carbohydrates, propionic acid, and butyric acid presented a linear increasing behavior, while organic matter, crude protein, ethereal extract, and non-fibrous carbohydrates presented a linear decreasing behavior $(\mathrm{P}<$ 0.05). Lactic acid and acetic acid concentrations for pornunça silage showed a quadratic behavior according to the increasing old man saltbush inclusion levels $(\mathrm{P}<0.05)$. The highest contribution of old man saltbush in the silages promoted changes in the profile of organic acids, allowing an improvement
\end{abstract}

1 Pesquisadores, Empresa Brasileira de Pesquisa Agropecuária, EMBRAPA Semiárido, Petrolina, PE, Brasil. E-mail: tadeu. voltolini@embrapa.br; gherman.araujo@embrapa.br; salete.moraes@embrapa.br

2 M.e em Ciência Animal, Programa de Pós-Graduação em Ciência Animal, Universidade Federal do Vale do São Francisco, UNIVASF, Petrolina, PE, Brasil. E-mail: kaio_agronomo@hotmail.com

3 Pós-Doutoranda, Programa de Pós-Graduação em Ciências Veterinárias no Semiárido, UNIVASF/CPGCVS, Petrolina, PE, Brasil. E-mail: glayciane gois@yahoo.com.br

4 Pós-Doutorando, Programa de Pós-Graduação em Ciência Animal e Pastagens, Universidade Federal Rural de Pernambuco, UFRPE/UAG, Garanhuns, PE, Brasil. E-mail: flemingcte@yahoo.com.br

* Author for correspondence

Received: Mar. 15, 2018 - Approved: June 26, 2019 
in silage quality, favoring lactic fermentation rather than acetic fermentation. Butyric acid contents were low for all treatments and indicated the control of undesirable fermentation processes. These results indicate that old man saltbush inclusion in silage composition may contribute to bromatological composition and fermentation process of the studied silages.

Key words: Food. Forage conservation. Semiarid.

\section{Resumo}

Objetivou-se avaliar a qualidade de silagens de leucena, gliricídia e pornunça com diferentes níveis de inclusão de erva sal em sua composição. Para tanto, foi adotado um delineamento experimental inteiramente casualizado, composto por 5 níveis de inclusão de erva sal (Atriplex numulária Lindl.) (0; 25; 50; 75 e 100\%) em silagens de Leucena (Leucaena leucocephala), Gliricídia (Gliricidia sepium) e Pornunça (Manihot sp.), com 5 repetições por tratamento, totalizando 75 mini silos experimentais que foram mantidos em galpão coberto e livre de animais oportunistas. Decorridos 100 dias da ensilagem, os silos foram abertos, desprezando-se a silagem dos primeiros $15 \mathrm{~cm}$ das extremidades dos silos. $\mathrm{O}$ material restante foi homogeneizado e amostrado para a determinação da composição bromatológica, digestibilidade in vitro e perfil fermentativo. Os níveis de inclusão de erva sal nas silagens de leucena promoveram um efeito linear negativo para matéria seca, matéria orgânica, proteína bruta, extrato etéreo, $\mathrm{pH}$ e nitrogênio amoniacal e um efeito linear positivo para matéria mineral, digestibilidade in vitro da matéria seca, carboidratos totais, carboidratos não fibrosos e ácido propiônico $(\mathrm{P}<0,05)$. Ainda para esta silagem, observou-se um efeito quadrático para o ácido lático. Nas silagens de gliricídia foi observado um comportamento linear positivo para as variáveis matéria seca, matéria mineral e carboidratos totais, já a matéria orgânica, proteína bruta e extrato etéreo apresentaram um comportamento linear negativo ( $\mathrm{P}$ $<0,05)$. Os teores de ácidos orgânicos lático, acético e propiônico apresentaram efeito quadrático para a silagem de glíricidia a medida em que se aumentavam os níveis de erva sal $(\mathrm{P}<0,05)$. Em relação a silagem de pornunça, as variáveis matéria seca, matéria mineral, carboidratos totais, ácido propiônico e ácido butírico apresentaram um comportamento linear crescente enquanto que as variáveis matéria orgânica, proteína bruta, extrato etéreo e carboidratos não fibrosos apresentaram comportamento linear decrescente $(\mathrm{P}<0,05)$. As concentrações de ácido lático e ácido acético para as silagens de pornunça apresentaram um comportamento quadrático de acordo com os crescentes níveis de inclusão de erva sal $(\mathrm{P}<0,05)$. A maior contribuição da erva sal nas silagens promoveu alterações no perfil de ácidos orgânicos, permitindo a melhora na qualidade das silagens, favorecendo a fermentação lática em detrimento a acética. Os teores de ácido butírico foram baixos para todos os tratamentos e indicam o controle de processos fermentativos indesejáveis. Os resultados indicam que a inclusão da erva sal na composição das silagens pode contribuir na composição bromatológica e com o processo fermentativo das silagens estudadas.

Palavras-chave: Alimentos. Conservação de forragem. Semiárido.

\section{Introduction}

Efficient forage production is the greatest challenge for animal production in the Brazilian semiarid region. In the dry season, the limited water supply in this region causes a decrease in plant biomass production, characterizing the seasonality of forage production. Thus, the use of crops that make better use of rainwater, as well as store water in their tissues, can be of great value to minimize the harmful effects of water scarcity (WICHELNS, 2015).

The use of supplementary roughage preserved as hay or silage could contribute to reducing this food deficiency by conferring production regularity on regional production systems, which represents an important competitive advantage in the search 
for consumer markets. There are several options of forage resources to be used in the strategic reserve of farms in the Brazilian semiarid region, among them species such as leucaena (Leucaena leucocephala), pornunça (Manihot sp.), and gliricidia (Gliricidia sepium), standing out by a forage production potential that can overcome $10,000 \mathrm{~kg} \mathrm{DM} / \mathrm{ha} /$ year and the protein content, which in most situations is higher than 20\% DM (BURNEY et al., 2014; ALVES et al., 2015; LEÃO et al., 2017; SANTOS et al., 2017).

In addition, conservation of forage resources in the form of silage with the maintenance of higher water contents is an additional advantage, mainly for drier regions with water limitations. However, these roughages (gliricidia, leucaena, and pornunça) present limitations for their preservation as silage. Gliricidia, leucaena, and pornunça have high protein contents of 23, 25, and 20\%, respectively (AKMAL et al., 2018; NASCIMENTO et al., 2016; NGUYEN et al., 2017), which may constitute in buffering capacity and impair the preservation process, causing a reduction in the $\mathrm{pH}$ drop rate of this material in the form of silage and increasing forage losses during the preservation period (BORREANI et al., 2018).

Old man saltbush (Atriplex nummularia) may be an alternative for improving fermentation patterns of silages within the forage preservation process due to its higher dry matter content associated with high salt contents, which can cause inhibition of the development of undesirable microorganisms by altering the $\mathrm{pH}$ and osmotic pressure of forage mass, thus improving its ensilability (MOURA et al., 2016).

Therefore, this study aimed to evaluate the quality of leucaena, gliricidia, and pornunça silages with different old man saltbush levels.

\section{Material and Methods}

The experiment was conducted at the Experimental Field of the Caatinga, in the Animal Metabolism Unit, belonging to the Brazilian Agricultural Research Corporation (EMBRAPA Semiárido), located in Petrolina, PE, Brazil. The average annual precipitation is $570 \mathrm{~mm}$, while the annual average maximum and minimum temperatures are 33.46 and $20.87^{\circ} \mathrm{C}$, respectively.

The experimental design was a completely randomized design consisting of five old man saltbush inclusion levels $(0,25,50,75$, and $100 \%)$ in leucaena, gliricidia, pornunça silages, with five replications per treatment. Forage was manually cut, being chopped in a forage machine (PP 35, Pinheiro Máquinas Agrícolas, Itapira, SP, Brazil) to obtain particles with a mean size of $2 \mathrm{~cm}$. The chopped material was homogenized according to the treatments in a concrete-mixer with capacity for 150 L (Menegotti Prime, São Paulo, SP, Brazil), and then ensiled. A sample of each chopped forage was collected for laboratory analysis.

Seventy-five silos were built in polyvinyl chloride (PVC) tubes with $10 \mathrm{~cm}$ in diameter and $50 \mathrm{~cm}$ long and a Bunsen valve for gas escape. Sand was placed at the bottom of the experimental minisilos, protected by a cotton cloth to avoid contact of forage with sand, allowing the effluent drainage. The forage masses with the proposed treatments were conditioned in the mini-silos in order to obtain a mean density of $650 \mathrm{~kg} / \mathrm{m}^{3}$. After capping, the silos were maintained in a covered shed free of opportunistic animals. Silos were opened after 100 days of ensilage, and the silage of the first $15 \mathrm{~cm}$ of their ends was discarded. The remaining material was homogenized and sampled for determining bromatological composition and fermentation profile, together with the forage sample before being ensiled. The bromatological composition of leucaena, gliricidia, pornunça, and old man saltbush is shown in Table 1. 
Table 1. Chemical composition of the forage plants used to make the silages.

\begin{tabular}{|c|c|c|c|c|}
\hline \multirow[b]{2}{*}{ Fraction } & \multicolumn{4}{|c|}{ Forage plants } \\
\hline & Leucaena & Gliricídia & Pornunça & Old man saltbush \\
\hline Dry matter $\left(\mathrm{g} \mathrm{kg}^{-1} \mathrm{NM}\right)$ & 367.9 & 25.67 & 239.4 & 369.7 \\
\hline Mineral matter $\left(\mathrm{g} \mathrm{kg}^{-1} \mathrm{DM}\right)$ & 72.8 & 90.5 & 65.3 & 175.2 \\
\hline Organic matter $\left(\mathrm{g} \mathrm{kg}^{-1} \mathrm{DM}\right)$ & 927.2 & 909.5 & 934.7 & 824.8 \\
\hline Crude protein $\left(\mathrm{g} \mathrm{kg}^{-1} \mathrm{DM}\right)$ & 224.5 & 157.9 & 166.6 & 62.2 \\
\hline Neutral detergent fiber $\left(\mathrm{g} \mathrm{kg}^{-1} \mathrm{DM}\right)$ & 631.6 & 642.4 & 592.6 & 670.8 \\
\hline Acid detergent fiber $\left(\mathrm{g} \mathrm{kg}^{-1} \mathrm{DM}\right)$ & 372.9 & 470.3 & 470.0 & 491.5 \\
\hline Ether extract $\left(\mathrm{g} \mathrm{kg}^{-1} \mathrm{DM}\right)$ & 19.9 & 23.7 & 50.1 & 8.1 \\
\hline IVDMD $\left(\mathrm{g} \mathrm{kg}^{-1} \mathrm{DM}\right)$ & 451.5 & 480.6 & 530.6 & 478.0 \\
\hline Total carbohydrates $\left(\mathrm{g} \mathrm{kg}^{-1} \mathrm{DM}\right)$ & 682.8 & 727.9 & 718.0 & 754.5 \\
\hline Non-fibrous carbohydrates $\left(\mathrm{g} \mathrm{kg}^{-1} \mathrm{DM}\right)$ & 51.2 & 85.5 & 125.4 & 83.7 \\
\hline
\end{tabular}

NM - Natural matter; DM- Dry matter; IVDMD - in vitro dry matter digestibility.

Samples of in natura material and silage after opening the silos were pre-dried in a forced ventilation oven at $55{ }^{\circ} \mathrm{C}$ for 72 hours, processed in a mill (Wiley mill, Marconi, MA-580, Piracicaba, Brazil) with 1-mm diameter sieves. Laboratory analyses were performed using the methods described by AOAC (2016) for dry matter (DM; method 967.03), mineral matter (MM; method 942.05), crude protein (CP; method 981.10), and ethereal extract (EE; method 920.29). Neutral detergent fiber (NDF) and acid detergent fiber (FDA) contents were determined as described by Van Soest et al. (1991).

In vitro dry matter digestibility (IVDMD) was determined according to the methodology described by Tilley and Terry (1963), considering the modifications proposed by Holden (1999). Total carbohydrates (TC) and non-fibrous carbohydrates (NFC) were obtained according to the methodology described by Sniffen et al. (1992), by means of the equations $\mathrm{TC}=100-(\% \mathrm{CP}+\% \mathrm{EE}+\% \mathrm{MM})$ and $\mathrm{NFC}=100-(\% \mathrm{CP}+\% \mathrm{EE}+\% \mathrm{NDF}+\mathrm{MM})$. At the time of opening of the silos, samples were collected for the $\mathrm{pH}$ evaluation using a potentiometer, according to the methodology described by Silva and Queiroz (2002), and for the determination of ammoniacal $\mathrm{N}$ content $\left(\mathrm{N}-\mathrm{NH}_{3}\right)$, according to the technique proposed by Fenner (1965) and adapted by Vieira (1980). The $\mathrm{N}-\mathrm{NH}_{3}$ content in relation to the total $\mathrm{N}(\mathrm{TN})$ was calculated by the equation $\mathrm{N}-\mathrm{NH}_{3}=($ ammoniacal $\mathrm{N} \times 100) \mathrm{TN}^{-1}$. The $\mathrm{TN}$ value was obtained by dividing $\mathrm{CP}$ values by factor 6.25 (SILVA; QUEIROZ, 2002).

Organic acids were analyzed according to the recommendations of Kung Junior and Ranjit (2001). Samples were prepared by the addition of $1 \mathrm{~mL}$ of $20 \%$ metaphosphoric acid $\mathrm{v} \mathrm{v}^{-1}$ in $2 \mathrm{~mL}$ of the silage filtrate, being then centrifuged. Analyses of organic acids (lactic, acetic, and butyric acids) were carried out by high-performance liquid chromatography (HPLC) at the Laboratory of Animal Nutrition of the Federal University of Minas Gerais (UFMG).

Silages had their fermentation processes classified as excellent (90-100 points), good (70-89 points), regular (50-69 points), bad (30-49 points), and very bad ( $<30$ points) according to the methodology proposed by Tomich et al. (2003), which considers the qualification of the silage fermentation process in relation to the $\mathrm{pH}$ value, associated with $\mathrm{DM}$ content, $\mathrm{N}-\mathrm{NH}_{3} / \mathrm{TN}$ concentration, and butyric and acetic acid contents. 
The data were submitted to analysis of variance (ANOVA) and regression, being later analyzed by the GLM procedure of SAS 9.2 (2011), considering as significant probability values lower than $5 \%$.

\section{Results and Discussion}

Old man saltbush inclusion affected bromatological characteristics of the silage $(\mathrm{P}<0.05)$ (Table 2). The dry matter content of leucaena silage decreased gradually with increasing old man saltbush levels (380.4 to $349.4 \%$ ), which was not observed in gliricidia and pornunça silages, which had their dry matter increased (27.33 to $36.84 \%$ for the gliricidia silage and 23.01 to $35.80 \%$ for the pornunça silage) as old man saltbush ratio increased due to the higher DM contents of the old man saltbush in relation to gliricidia and pornunça.

In general, DM contents of silages were close to the recommended range for good silage, ranging from 30 to 35\% DM (MCDONALD et al., 1991). According to Tolentino et al. (2016), a dry matter content equal to or higher than $20 \%$ associated with an adequate soluble carbohydrate content would be sufficient to produce good quality silage.

Table 2. Bromatological composition of leucaena, gliricidia and pornunça silages with different levels of old man saltbush.

\begin{tabular}{|c|c|c|c|c|c|c|}
\hline \multirow{3}{*}{ Fraction } & \multicolumn{5}{|c|}{ Levels of old man saltbush (\%) } & \multirow{3}{*}{ MSE } \\
\hline & 0 & 25 & 50 & 75 & 100 & \\
\hline & \multicolumn{5}{|c|}{ Leucaena silage } & \\
\hline Dry matter $\left(\mathrm{g} \mathrm{kg}^{-1} \mathrm{NM}\right)^{1}$ & 380.4 & 375.2 & 373.3 & 377.6 & 349.4 & 0.19 \\
\hline Mineral matter $\left(\mathrm{g} \mathrm{kg}^{-1} \mathrm{DM}\right)^{2}$ & 74.4 & 100.2 & 117.0 & 132.4 & 163.7 & 0.12 \\
\hline Organic matter $\left(\mathrm{g} \mathrm{kg}^{-1} \mathrm{DM}\right)^{3}$ & 925.6 & 899.8 & 883.0 & 867.6 & 836.3 & 0.16 \\
\hline Crude protein $\left(\mathrm{g} \mathrm{kg}^{-1} \mathrm{DM}\right)^{4}$ & 186.2 & 166.6 & 123.7 & 81.0 & 63.0 & 0.21 \\
\hline Neutral detergent fiber $\left(\mathrm{g} \mathrm{kg}^{-1} \mathrm{DM}\right)$ & 631.6 & 607.9 & 599.8 & 617.5 & 569.1 & 0.54 \\
\hline Acid detergent fiber ( $\left.\mathrm{g} \mathrm{kg}^{-1} \mathrm{DM}\right)$ & 465.8 & 415.3 & 429.2 & 470.8 & 446.8 & 0.71 \\
\hline Ether extract $\left(\mathrm{g} \mathrm{kg}^{-1} \mathrm{DM}\right)^{5}$ & 14.2 & 18.4 & 14.9 & 9.2 & 9.7 & 0.05 \\
\hline IVDMD $\left(\mathrm{g} \mathrm{kg}^{-1} \mathrm{DM}\right)^{6}$ & 40.92 & 467.3 & 468.6 & 524.8 & 515.8 & 0.56 \\
\hline Total carbohydrates $\left(\mathrm{g} \mathrm{kg}^{-1} \mathrm{DM}\right)^{7}$ & 725.1 & 714.7 & 744.3 & 777.3 & 763.4 & 0.34 \\
\hline \multirow{2}{*}{ Non-fibrous carbohydrates $\left(\mathrm{g} \mathrm{kg}^{-1} \mathrm{DM}\right)^{8}$} & 93.5 & 106.7 & 144.6 & 159.8 & 194.3 & 0.46 \\
\hline & \multicolumn{5}{|c|}{ Gliricídia silage } & \\
\hline Dry matter $\left(\mathrm{g} \mathrm{kg}^{-1} \mathrm{NM}\right)^{9}$ & 27.33 & 29.83 & 32.50 & 35.32 & 36.84 & 0.15 \\
\hline Mineral matter $\left(\mathrm{g} \mathrm{kg}^{-1} \mathrm{DM}\right)^{10}$ & 9.29 & 11.11 & 12.85 & 14.96 & 16.20 & 0.11 \\
\hline Organic matter $\left(\mathrm{g} \mathrm{kg}^{-1} \mathrm{DM}\right)^{11}$ & 90.71 & 88.88 & 87.15 & 85.03 & 83.79 & 0.11 \\
\hline Crude protein $\left(\mathrm{g} \mathrm{kg}^{-1} \mathrm{DM}\right)^{12}$ & 14.87 & 11.87 & 9.91 & 8.19 & 6.17 & 0.21 \\
\hline Neutral detergent fiber $\left(\mathrm{g} \mathrm{kg}^{-1} \mathrm{DM}\right)$ & 57.69 & 60.54 & 62.24 & 63.50 & 62.27 & 1.90 \\
\hline Acid detergent fiber $\left(\mathrm{g} \mathrm{kg}^{-1} \mathrm{DM}\right)$ & 48.70 & 50.07 & 49.95 & 48.76 & 46.45 & 1.18 \\
\hline Ether extract $\left(\mathrm{g} \mathrm{kg}^{-1} \mathrm{DM}\right)^{13}$ & 2.76 & 2.25 & 1.42 & 1.71 & 1.5 & 0.08 \\
\hline IVDMD $\left(\mathrm{g} \mathrm{kg}^{-1} \mathrm{DM}\right)$ & 46.17 & 45.17 & 46.58 & 45.63 & 45.98 & 1.06 \\
\hline Total carbohydrates $\left(\mathrm{g} \mathrm{kg}^{-1} \mathrm{DM}\right)^{14}$ & 72.12 & 74.74 & 75.79 & 75.11 & 76.00 & 0.27 \\
\hline Non-fibrous carbohydrates ( $\left.\mathrm{g} \mathrm{kg}^{-1} \mathrm{DM}\right)$ & 13.61 & 14.20 & 13.60 & 12.70 & 13.72 & 0.39 \\
\hline
\end{tabular}


continuation

\begin{tabular}{|c|c|c|c|c|c|c|}
\hline \multirow[b]{2}{*}{ Matéria seca $\left(\mathrm{g} \mathrm{kg}^{-1} \mathrm{NM}\right)^{15}$} & \multicolumn{5}{|c|}{ Pornunça Silage } & \multirow[b]{2}{*}{0.22} \\
\hline & 23.01 & 27.86 & 29.07 & 33.41 & 35.80 & \\
\hline Mineral matter $\left(\mathrm{g} \mathrm{kg}^{-1} \mathrm{DM}\right)^{16}$ & 6.65 & 10.98 & 12.28 & 14.32 & 15.69 & 0.21 \\
\hline Organic matter $\left(\mathrm{g} \mathrm{kg}^{-1} \mathrm{DM}\right)^{17}$ & 93.25 & 89.02 & 87.72 & 85.68 & 84.31 & 0.21 \\
\hline Crude protein $\left(\mathrm{g} \mathrm{kg}^{-1} \mathrm{DM}\right)^{18}$ & 15.09 & 12.07 & 8.89 & 7.23 & 6.17 & 0.22 \\
\hline Neutral detergent fiber ( $\left.\mathrm{g} \mathrm{kg}^{-1} \mathrm{DM}\right)$ & 53.92 & 55.15 & 60.28 & 61.42 & 60.51 & 0.69 \\
\hline Acid detergent fiber $\left(\mathrm{g} \mathrm{kg}^{-1} \mathrm{DM}\right)$ & 52.50 & 45.93 & 50.99 & 48.61 & 48.36 & 0.72 \\
\hline Ether extract $\left(\mathrm{g} \mathrm{kg}^{-1} \mathrm{DM}\right)^{19}$ & 4.57 & 3.39 & 2.51 & 1.65 & 1.35 & 0.15 \\
\hline $\operatorname{IVDMD}\left(\mathrm{g} \mathrm{kg}^{-1} \mathrm{DM}\right)$ & 51.76 & 53.98 & 52.12 & 51.74 & 51.02 & 0.34 \\
\hline Total carbohydrates $\left(\mathrm{g} \mathrm{kg}^{-1} \mathrm{DM}\right)^{20}$ & 73.66 & 73.54 & 76.29 & 76.77 & 76.77 & 0.29 \\
\hline Non-fibrous carbohydrates $\left(\mathrm{g} \mathrm{kg}^{-1} \mathrm{DM}\right)^{21}$ & 197.3 & 183.7 & 184.9 & 167.2 & 162.5 & 0.27 \\
\hline
\end{tabular}

NM - Natural matter; DM- Dry matter; IVDMD - in vitro dry matter digestibility; MSE - Mean standard error

Equations - Leucaena Silage: $\hat{\mathrm{Y}}^{1}=38.312-0.02 \mathrm{x}, \mathrm{R}^{2}=0.43 ; \hat{\mathrm{Y}}^{2}=7.538+0.08 \mathrm{x}, \mathrm{R}^{2}=0.94 ; \hat{\mathrm{Y}}^{3}=92.462-0.08 \mathrm{x}, \mathrm{R}^{2}=0.94 ; \hat{\mathrm{Y}}^{4}=19.049-$ $0.13 \mathrm{x}, \mathrm{R}^{2}=0.96 ; \hat{\mathrm{Y}}^{5}=1.695-0.007 \mathrm{x}, \mathrm{R}^{2}=0.54 ; \hat{\mathrm{Y}}^{6}=41.402+0.09 \mathrm{x}, \mathrm{R}^{2}=0.66 ; \hat{\mathrm{Y}}^{7}=71.716+0.05 \mathrm{x}, \mathrm{R}^{2}=0.61 ; \hat{\mathrm{Y}}^{8}=8.891+0.10 \mathrm{x}, \mathrm{R}^{2}$ $=0.74$.

Gliricidia Silage: $\hat{\mathrm{Y}}^{9}=24.026+0.085 \mathrm{x}, \mathrm{R}^{2}=0.96 ; \hat{\mathrm{Y}}^{10}=9.347+0.07 \mathrm{x}, \mathrm{R}^{2}=0.95 ; \hat{\mathrm{Y}}^{11}=90.652-0.07 \mathrm{x}, \mathrm{R}^{2}=0.95 ; \hat{\mathrm{Y}}^{12}=14.402-0.083 \mathrm{x}$, $\mathrm{R}^{2}=0.90 ; \hat{\mathrm{Y}}^{13}=2.548-0.012 \mathrm{x}, \mathrm{R}^{2}=0.58 ; \hat{\mathrm{Y}}^{14}=73.139+0.03 \mathrm{x}, \mathrm{R}^{2}=0.46$.

Pornunça Silage: $\hat{\mathrm{Y}}^{15}=23.61+0.12 \mathrm{x}, \mathrm{R}^{2}=0.9 ; \hat{\mathrm{Y}}^{16}=7.70+0.08 \mathrm{x}, \mathrm{R}^{2}=0.91 ; \hat{\mathrm{Y}}^{17}=92.29-0.09 \mathrm{x}, \mathrm{R}^{2}=0.91 ; \hat{\mathrm{Y}}^{18}=14.43-0.09 \mathrm{x}, \mathrm{R}^{2}$ $=0.91 ; \hat{\mathrm{Y}}^{19}=4.34-0.03 \mathrm{x}, \mathrm{R}^{2}=0.74 ; \hat{\mathrm{Y}}^{20}=73.52+0.03 \mathrm{x}, \mathrm{R}^{2}=0.50 ; \hat{\mathrm{Y}}^{21}=19.64-0.03 \mathrm{x}, \mathrm{R}^{2}=0.50$.

The increase of old man saltbush inclusion promoted higher $\mathrm{MM}$ contents and lower $\mathrm{OM}$ contents $(\mathrm{P}<0.05)$ in the studied silages due to a higher contribution of minerals present in this forage. According to Flowers et al. (2015), old man saltbush presents high contents of salts, thus being an alternative source of minerals.

A reduction in $\mathrm{CP}$ contents was observed with the increase old man saltbush inclusion in the evaluated silages $(\mathrm{P}<0.05)$ due to their higher $\mathrm{CP}$ contents $(18.62,14.87$, and $15.09 \%$ CP for leucaena, gliricidia, and pornunça, respectively) in relation to old man saltbush $(6.17 \% \mathrm{CP})$, justifying the lower $\mathrm{CP}$ values as old man saltbush increased. Silages presented CP contents above $7 \%$, estimated by Church (1988) so that a sufficient nitrogen supply is available to the effective microbial fermentation in the rumen. The minimum level of protein in ruminant diets avoids limiting fiber degradation by rumen microorganisms, thus meeting the minimum requirement for the proper functioning of rumen microorganisms (COSTA et al., 2016).
The mean NDF and ADF contents of silages were not affected $(\mathrm{P}>0.05)$ by old man saltbush inclusion, possibly due to the similar values of NDF and ADF of the two forage masses. These mean NDF and ADF contents of silages are in agreement with the values reported by Edvan et al. (2013), who evaluated the bromatological composition of gliricidia silages and observed values of $64.18 \%$ for NDF and $46.50 \%$ for ADF, and the studies conducted by Backes et al. (2014) and Silva et al. (2011), who evaluated the bromatological composition of maniçoba silages and reported values of NDF of 52.6 and $50.82 \%$ and ADF of 46.9 and $38.07 \%$, respectively.

The IVDMD presented a difference between treatments $(\mathrm{P}<0.05)$ for leucaena silage, with minimum and maximum values of 40.92 and $52.48 \%$, respectively (Table 2 ). These values are below those found by Souza et al. (2015), who evaluated IVDMD of leucaena and obtained $64.73 \%$ of digestibility. IVDMD was not influenced $(\mathrm{P}>0.05)$ by old man saltbush inclusion levels in gliricidia and pornunça silages, which can also be 
explained by similar values of IVDMD between the two sources because gliricidia and pornunça had in vitro digestibility values of 480.6 and $53.06 \mathrm{~g}$ $\mathrm{kg}^{-1}$, respectively, and old man saltbush presented IVDMD of $478.0 \mathrm{~g} \mathrm{~kg}^{-1}$ before ensiling. In general, IVDMD values of silages in this study can be considered low, with a mean of $45.91 \%$. Barreto (2008) found IVDMD values of the order of $50.25 \%$ for gliricidia silage, which may be related to the lower advanced age of the harvested material when compared to that of the present study.

The values of EE of silages was influenced by old man saltbush inclusion $(\mathrm{P}<0.05)$, with a low $\mathrm{EE}$ content as old man saltbush inclusion increased, which is justified by lower EE contents in the old man saltbush in relation to leucaena, gliricidia, and pornunça before ensilage. The decrease in fat content as a function of the percentages of old man saltbush seems to be related to the higher EE content of forages used in relation to old man saltbush since there was a decrease in their proportions (Table 2). According to NRC (2007), total fat in the diet should not exceed 6 to $7 \%$ in DM, as it may lead to reductions in ruminal fermentation, fiber digestibility, and passage rate. The studied silages had adequate fat content.
A linear increasing effect $(\mathrm{P}<0.05)$ was observed for TC, varying in leucaena (714.7 to $763.4 \mathrm{~g} \mathrm{~kg}^{-1}$ ), gliricidia (721.2 to $760.0 \mathrm{~g} \mathrm{~kg}^{-1}$ ), and pornunça silages ( 735.4 to $767.7 \mathrm{~g} \mathrm{~kg}^{-1}$ ) with old man saltbush inclusion. Similar behavior was observed for NFC contents in leucaena silage, i.e., NFC contents ( 93.5 to $194.3 \mathrm{~g} \mathrm{~kg}^{-1}$ ) increased as old man saltbush was added (Table 2). An inversely proportional result was observed for pornunça silage $(\mathrm{P}<0.05)$, in which NFC contents (197.3 to $162.5 \mathrm{~g} \mathrm{~kg}^{-1}$ ) decreased as old man saltbush levels increased. The lowest CP $\left(62.2 \mathrm{~g} \mathrm{~kg}^{-1}\right)$ and EE contents $(8.1 \mathrm{~g}$ $\mathrm{kg}^{-1}$ ) of old man saltbush associated with leucaena in the form of silage contributed to the higher NFC values. However, the reduction of NCF values in the pornunça silage is due to an increase in NDF contents (63.92 to $60.51 \%)$ in the silage (Table 2) through higher levels of this nutrient in the old man saltbush $(67.08 \%)$ when compared to pornunça (59.26\%) (Table 1).

Old man saltbush inclusion affected the $\mathrm{pH}$ values $(\mathrm{P}<0.05)$ (Table 3 ) of leucaena silages, with decreased $\mathrm{pH}$ values as old man saltbush inclusion levels increased, reaching a mean of 4.25. In general, the $\mathrm{pH}$ of silages was within the $\mathrm{pH}$ range considered normal (3.6 to 4.2) for good quality silages (MCDONALD et al., 1991).

Table 3. $\mathrm{pH}$, ammoniacal nitrogen $\left(\mathrm{NH}_{3}-\mathrm{N}\right)$ and organic acids production in leucaena, gliricidia and pornunça silages with different levels of old man saltbush.

\begin{tabular}{|c|c|c|c|c|c|c|}
\hline \multirow{3}{*}{ Variables } & \multicolumn{5}{|c|}{ Levels of old man saltbush (\%) } & \multirow{3}{*}{ MSE } \\
\hline & 0 & 25 & 50 & 75 & 100 & \\
\hline & \multicolumn{5}{|c|}{ Leucaena silage } & \\
\hline $\mathrm{pH}^{1}$ & 4.77 & 4.41 & 4.17 & 3.92 & 4.00 & 0.03 \\
\hline $\mathrm{NH}_{3}-\mathrm{N}\left(\mathrm{g} \mathrm{kg}^{-1} \mathrm{NM}\right)^{2}$ & 120.8 & 100.0 & 86.6 & 76.0 & 73.8 & 0.20 \\
\hline Lactic acid $\left(\mathrm{g} \mathrm{kg}^{-1} \mathrm{NM}\right)^{3}$ & 44.4 & 32.9 & 34.5 & 32.9 & 33.5 & 0.07 \\
\hline Acetic acid $\left(\mathrm{g} \mathrm{kg}^{-1} \mathrm{NM}\right)$ & 17.9 & 27.3 & 27.4 & 5.3 & 33.6 & 0.21 \\
\hline Propionic acid $\left(\mathrm{g} \mathrm{kg}^{-1} \mathrm{NM}\right)^{4}$ & 1.4 & 1.3 & 3.5 & 1.4 & 4.3 & 0.02 \\
\hline Butyric acid $\left(\mathrm{g} \mathrm{kg}^{-1} \mathrm{NM}\right)$ & 0.3 & 0.2 & 0.3 & 0.3 & 0.2 & 0.01 \\
\hline
\end{tabular}


continuation

\begin{tabular}{|c|c|c|c|c|c|c|}
\hline \multicolumn{7}{|c|}{ Gliricídia silage } \\
\hline $\mathrm{pH}$ & 4.16 & 4.20 & 4.18 & 4.21 & 4.27 & 0.04 \\
\hline $\mathrm{NH}_{3}-\mathrm{N}\left(\mathrm{g} \mathrm{kg}^{-1} \mathrm{NM}\right)$ & 64.6 & 69.7 & 60.9 & 63.8 & 55.7 & 0.26 \\
\hline Lactic acid $\left(\mathrm{g} \mathrm{kg}^{-1} \mathrm{NM}\right)^{5}$ & 48.4 & 108.5 & 116.4 & 55.3 & 55.4 & 0.41 \\
\hline Acetic acid $\left(\mathrm{g} \mathrm{kg}^{-1} \mathrm{NM}\right)^{6}$ & 12.3 & 105.3 & 106.4 & 17.5 & 2.45 & 0.06 \\
\hline Propionic acid $\left(\mathrm{g} \mathrm{kg}^{-1} \mathrm{NM}\right)^{7}$ & 3.4 & 4.6 & 4.5 & 4.5 & 4.4 & 0.01 \\
\hline Butyric acid $\left(\mathrm{g} \mathrm{kg}^{-1} \mathrm{NM}\right)$ & 0.2 & 0.4 & 0.3 & 0.2 & 0.4 & 0.01 \\
\hline \multicolumn{7}{|c|}{ Pornunça silage } \\
\hline $\mathrm{pH}$ & 3.66 & 3.65 & 3.69 & 3.67 & 3.67 & 0.02 \\
\hline $\mathrm{NH}_{3}-\mathrm{N}\left(\mathrm{g} \mathrm{kg}^{-1} \mathrm{NM}\right)$ & 54.7 & 59.3 & 57.8 & 56.2 & 53.2 & 0.22 \\
\hline Lactic acid $\left(\mathrm{g} \mathrm{kg}^{-1} \mathrm{NM}\right)^{8}$ & 38.5 & 58.6 & 69.5 & 49.1 & 59.5 & 0.20 \\
\hline Acetic acid $\left(\mathrm{g} \mathrm{kg}^{-1} \mathrm{NM}\right)^{9}$ & 11.3 & 45.3 & 51.5 & 9.1 & 12.4 & 0.07 \\
\hline Propionic acid $\left(\mathrm{g} \mathrm{kg}^{-1} \mathrm{NM}\right)^{10}$ & 3.6 & 3.4 & 3.5 & 4.2 & 5.4 & 0.01 \\
\hline Butyric acid $\left(\mathrm{g} \mathrm{kg}^{-1} \mathrm{NM}\right)^{11}$ & 0.1 & 0.2 & 0.2 & 0.3 & 0.3 & 0.01 \\
\hline
\end{tabular}

NM - Natural matter; DM- Dry matter; IVDMD - in vitro dry matter digestibility; MSE - Mean standard error

Equations - Leucaena silage: $\hat{\mathrm{Y}}^{1}=4.665-0.008 \mathrm{x}, \mathrm{R}^{2}=0.85 ; \hat{\mathrm{Y}}^{2}=11.720-0.05 \mathrm{x}, \mathrm{R}^{2}=0.84 ; \hat{\mathrm{Y}}^{3}=4.314-0.03 \mathrm{x}+0.0002 \mathrm{x}^{2}, \mathrm{R}^{2}=0.62$; $\hat{\mathrm{Y}}^{4}=0.125+0.002 \mathrm{x}, \mathrm{R}^{2}=0.41$.

Gliricidia silage: $\hat{\mathrm{Y}}^{5}=5.777+0.200 \mathrm{x}-0.002 \mathrm{x}^{2}, \mathrm{R}^{2}=0.62 ; \hat{\mathrm{Y}}^{6}=2.854+0.273 \mathrm{x}-0.002 \mathrm{x}^{2}, \mathrm{R}^{2}=0.56 ; \hat{\mathrm{Y}}^{7}=0.363+0.003 \mathrm{x}-0.000 \mathrm{x}^{2}, \mathrm{R}^{2}$ $=0.65$.

Pornunça silage: $\hat{\mathrm{Y}}^{8}=4.129+0.071 \mathrm{x}-0.0005 \mathrm{x}^{2}, \mathrm{R}^{2}=0.42 . \hat{\mathrm{Y}}^{9}=1.714+0.111 \mathrm{x}-0.001 \mathrm{x}^{2}, \mathrm{R}^{2}=0.60 ; \hat{\mathrm{Y}}^{10}=0.325+0.001 \mathrm{x}, \mathrm{R}^{2}=0.60$; $\hat{\mathrm{Y}}^{11}=0.021+0.0002 \mathrm{x}, \mathrm{R}^{2}=0.53$.

Leucaena silage without old man saltbush inclusion had a higher $\mathrm{NH}_{3}-\mathrm{N}$ value (12.08\%) when compared to the other treatments. According to McDonald et al. (1991), higher values of $\mathrm{NH}_{3}-\mathrm{N}$ /TN indicate marked amino acid degradation processes and other nitrogenous compounds by microorganism action, altering the course of fermentation by increasing the buffering capacity, which prevents a rapid $\mathrm{pH}$ drop of the ensiled material and compromises silage quality. The other silages remained below the range considered acceptable, i.e., below $10 \%$ in relation to total nitrogen, presenting satisfactory contents.

Organic acids were influenced $(\mathrm{P}<0.05)$ by the increasing old man saltbush inclusion in the silages. The lactic acid concentration in the studied silages had a quadratic behavior. In this case, the highest lactic acid content in the leucaena silage evidenced that this species affected this parameter due to the protein content $(22.45 \%)$ that the plant presents, which may be related to the higher nitrogen availability for the metabolism of lactobacilli. According to Cysneiros et al. (2013), the enzymes released in the ensilage due to cell rupture as a function of forage cut, as well as microbial enzymes, hydrolyze proteins and produce peptides and free amino acids, in addition to polymerized carbohydrates to simple sugars, supplying the substrate for microorganisms such as yeasts, fungi, and aerobic and anaerobic bacteria.

The lowest values of lactic acid in gliricidia (48.4 $\left.\mathrm{g} \mathrm{kg}^{-1}\right)$ and pornunça silages $\left(38.5 \mathrm{~g} \mathrm{~kg}^{-1}\right)$ were probably due to the low dry matter content of 273.3 and $231.0 \mathrm{~g} \mathrm{~kg}^{-1}$, respectively. According to Jobim and Nussio (2013), a suitable dry matter content for a good forage fermentation in the silo is between 28 to $40 \%$. Values below $28 \% \mathrm{DM}$ favor the action of undesirable microorganisms in the ensiled material. According to Borreani et al. (2018), excess moisture at ensilage time implies risks due to the action of undesirable microorganisms. The high water activity (Aw) at this moment favors the development of 
bacteria, especially those of the genus Clostridium and of bacteria that break down sugars, lactic acid, proteins, and amino acids into acetic and butyric acids, ammonia, and amines, which are substances that influence silage consumption (OLADOSU et al., 2016; JOVAIŠIENE et al., 2017).

The acetic acid presented a quadratic behavior for gliricidia and pornunça silages, with the presence of acetic acid at levels above $2 \%$ within the treatments, which may demonstrate the action of enterobacteria in these silos and would lead to a reduction of silage consumption by animals (MCDONALD et al., 1991). This result may be due to poor compaction at these levels since the other treatments are within this recommendation.

A significant effect was observed for propionic acid content with old man saltbush inclusion levels in all studied silages, with results within the range $(<0.50 \%$ DM) established by Rêgo et al. (2015) and Borreani et al. (2018). Propionic acid production is associated with the conversion of lactic acid into acetic acid and 1,2-propanediol, which in turn is converted into propionic acid and 1-propanol by microorganisms that occur naturally in silages (CARVALHO et al., 2012).

A linear behavior was observed for butyric acid contents in pornunça silages with increasing old man saltbush levels $(\mathrm{P}<0.05)$. Butyric acid content reflects the extent of clostridial activity and is related to higher final $\mathrm{pH}$ values. According to Hafner et al. (2013), values below $0.3 \%$ indicate lower losses of energy and dry matter. Thus, the observed values indicated an adequate fermentation process in the evaluated silages.

Based on the criteria for evaluating the quality of the fermentation process suggested by Tomich et al. (2003), leucaena, gliricidia, and pornunça silages at levels of 0,50 , and $75 \%$ presented scores of 85 or 80 , being considered good quality silages. The other silages scored 90 or 95 , being classified as of excellent quality (Table 4).

Table 4. Classification of the fermentative process in leucaena, gliricidia and pornunça silages with different levels of old man saltbush.

\begin{tabular}{|c|c|c|c|c|c|}
\hline \multirow{2}{*}{ Silage } & \multicolumn{5}{|c|}{ Levels of old man saltbush (\%) } \\
\hline & 0 & 25 & 50 & 75 & 100 \\
\hline Leucaena & Good & Great & Great & Great & Great \\
\hline Gliricídia & Good & Great & Good & Good & Great \\
\hline Pornunça & Great & Great & Good & Great & Great \\
\hline
\end{tabular}

* Qualification carried out according to the evaluation methodology proposed by Tomich et al. (2003).

Bromatological composition and fermentation profile values of leucaena, gliricidia, and pornunça silages showed that these forage plants could be preserved in the form of silage, being equivalent or even superior to the silages of other tropical forages already used in feeding ruminants in other Brazilian regions.

\section{Conclusion}

The highest contribution of old man saltbush in the silages promoted changes in the profile of organic acids, allowing an improvement in silage quality, favoring lactic fermentation rather than acetic fermentation. Butyric acid contents were low for all treatments and indicated the control of undesirable fermentation processes. These results indicate that 
old man saltbush inclusion in silage composition may contribute to bromatological composition and fermentation process of the studied silages.

\section{Acknowledgments}

To the Fundação de Amparo a Ciência e Tecnologia do Estado da Paraíba (FAPESQ) for granting the scholarship. To the Brazilian Development Bank (BNDES) for financial support.

\section{References}

AKMAL, JAMARUN, N.; ZAIN, M. Ability of dwarf elephant grass (Pennisetum purpureum cv. Mott) and Gliricidia sepium to capture ammonia $\left(\mathrm{NH}_{3}\right)$ around chicken cages: An in vitro evaluation. Pakistan Journal of Nutrition, Faisalabad, v. 17, n. 6, p. 306-310, 2018. DOI: $10.3923 /$ pjn.2018.306.310.

ALVES, A. A.; REIS, E. M.; SILVA NETO, M. F. Forrageiras indicadas para alimentação animal no Semiárido brasileiro. Petrolina: EMBRAPA Semiárido, 2015. $62 \mathrm{p}$.

ASSOCIATION OF OFFICIAL ANALYTICAL CHEMISTS - AOAC. Official methods of analysis of AOAC International. 20 $0^{\text {th }}$ ed. Washington: Ed. Latimer Jr., G.W., 2016. 3100 p.

BACKES, A. A.; SANTOS, L. L.; FAGUNDES, J. L.; BARBOSA, L. T.; MOTA, M.; VIEIRA, J. S. Valor nutritivo da silagem de maniçoba (Manihot pseudoglaziovii) com e sem fubá de milho como aditivo. Revista Brasileira de Saúde e Produção Animal, Salvador, v. 15 , n. 1, p. 182-191, 2014. DOI: $10.1590 /$ S1519-99402014000100016

BARRETO, D.C. Composição bromatológica de silagem de Gliricídia. 2008. Dissertação (Mestrado em Zootecnia) - Universidade Estadual do Sudoeste da Bahia, Itapetinga.

BORREANI, G.; TABACCO, E.; SCHMIDT, R. J.; HOLMES, B. J.; MUCK, R. E. Silage review: factors affecting dry matter and quality losses in silages. Journal of Dairy Science, Champaign, v. 101, n. 5, p. 3952-3979, 2018. DOI: $10.3168 /$ jds.2017-13837

BURNEY, J.; CESANO, D.; RUSSELL, J.; LA ROVERE, E. L.; CORRAL, T.; COELHO, N. S.; SANTOS, L. Climate change adaptation strategies for smallholder farmers in the Brazilian Sertão. Climatic Change, Switzerland, v. 126, n. 1/2, p. 45-59, 2014. DOI:
$10.1007 / \mathrm{s} 10584-014-1186-0$

CARVALHO, B. F.; AVILA, C. L. S.; PINTO, M. N.; SCHWAN, R. F. Effects of propionic acid and Lactobacillus buchneri (UFLA SIL 72) addition on fermentative and microbiological characteristics of sugar cane silage treated with and without calcium oxide. Grass and Forage Science, Europe, v. 67, n. 4, p. 462471, 2012. DOI: 10.1111/j.1365-2494.2012.00863.x

$\mathrm{CHURCH}, \mathrm{D}$. C. The ruminant animal digestive physiology and nutrition. New Jersey: Prentice Hall, 1988. $564 \mathrm{p}$.

COSTA, C. S.; RODRIGUES, R. C.; ARAÚJO, R. A.; SOUZA, F. B. F.; SANTOS, F. N. S.; COSTA, F. O.; RODRIGUES, M. M.; MENDES, S. S. Composição química e degradabilidade in situ de silagens de capimMarandu com farelo de babaçu. Revista Brasileira de Saúde e Produção Animal, Salvador, v. 17, n. 4, p. 572583, 2016. DOI: 10.1590/S1519-99402016000400002

CYSNEIROS, C. S. S.; FERREIRA, R. N.; OLIVEIRA, M. A.; FAVORETTO, A. O.; ARNHOLD, E.; ULHOA, C. J. Produção, caracterização e avaliação de enzimas fibrolíticas na digestibilidade da forragem de milho. Ciência Animal Brasileira, Goiânia, 14, n. 4, p. 426-435, 2013. DOI: 10.5216/cab.v14I4.19491

EDVAN, R. L.; CARNEIRO, M. S. S.; COUTINHO, M. J. F.; SILVA, E. B.; OLIVEIRA, G. S.; SILVA, M. S. M.; ALBUQUERQUE, D. R. Perdas e composição bromatológica de silagem de gliricídia contendo diferentes níveis de vagem de algaroba. Tecnologia e Ciência Agropecuária, João Pessoa, v. 7, n. 2, p. 63-68, 2013. Disponível em: http://revistatca.pb.gov.br/edicoes/ volume-07-2013/volume-7-numero-2-junho-2013/ tca7210.pdf. Acesso em: 08 jan. 2018.

FENNER, H. Methods for determining total volatile bases in rumen fluid by steam distillation. Journal Dairy Science, Elsevier, v. 48, n. 5, p. 249-251, 1965. DOI: 10.3168/jds.S0022-0302(65)88206-6

FLOWERS, T. J.; MUNNS, R.; COLMER, T. D. Sodium chloride toxicity and the cellular basis of salt tolerance in halophytes. Annals of Botany, Bethesda, v. 115, n. 3, p. 419-431, 2015. DOI: 10.1093/aob/mcu217

HAFNER, S. D.; HOWARD, C.; MUCK, R. E.; FRANCO, R. B.; MONTESA, F.; GREEN, P. G.; MITLOHNER, F.; TRABUE, S. L.; ROTZ, C. A. Emission of volatile organic compounds from silage: compounds, sources, and implications. Atmospheric Environment, Elsevier v. 77, n. 1, p. 827-839, 2013. DOI: 10.1016/j.atmosenv.2013.04.076

HOLDEN, L. A. Comparison of methods of in vitro dry matter digestibility for ten feeds. Journal of Dairy 
Science, Champaign, v. 82, n. 8, p. 1791-1794, 1999. DOI: $10.3168 /$ jds.S0022-0302(99)75409-3

JOBIM, C. C.; NUSSIO, L. G. Princípios básicos da fermentaçãona ensilagem. In: REIS, R.A.;BERNARDES, T. F.; SIQUEIRA, G. R. (Ed.). Forragicultura: ciência, tecnologia e gestão de recursos forrageiros. Jaboticabal: Multipress, 2013. p. 649-660.

JOVAIŠIENĖ, J.; BAKUTIS, B.; BALIUKONIENĖ, V.; MATUSEVIČIUS, P.; LIPIŃSKI, K.; ANTOSZKIEWICZ, Z.; FIJAŁKOWSKA, M. Biogenic amines and mycotoxins concentrations in baled silage from organic and conventional farms. Arquivo Brasileiro de Medicina Veterinária e Zootecnia, Belo Horizonte, v. 69 , n. 2, p. 269-277, 2017. DOI: $10.1590 / 1678-4162-$ 9130

KUNG JUNIOR, L.; RANJIT, N. K. The effect of Lactobacillus buchneri and other additives on the fermentation and aerobic stability of barley silage. Journal Dairy Science, Elsevier, v. 84, n. 5, p. 11491155, 2001. DOI: $10.3168 /$ jds.S0022-0302(01)74575-4

LEÃO, G. F. M.; JOBIM, C. C.; NEUMANN, M.; HORST, E. H.; SANTOS, S. K.; VENANCIO, B. J.; SANTOS, L. C. Nutritional composition and aerobic stability of winter cereal silage at different storage times. Acta Scientiarum. Animal Sciences, Maringá, v. 39, n. 2, p. 131-136, 2017. DOI: 10.4025/actascianimsci. v39i2.34270

MCDONALD, P.; HENDERSON, A. R.; HERON, S. J. E. The biochemistry of silage. $2^{\text {th }}$ ed. Marlow: Chalcombe Pub, 1991. 340 p.

MOURA, E. S. R.; COSME, C. R.; DIAS, N. S.; PORTELA, J. C.; SOUZA, A. C. M. Yield and forage quality of saltbush irrigated with reject brine from desalination plant by reverse osmosis. Revista Caatinga, Mossoró, v. 29, n. 1, p. 1-10, 2016. DOI: 10.1590/1983-21252016v29n101rc

NASCIMENTO, J. M. L.; MENEZES, K. M. S.; QUEIROZ, M. A. Á.; MELO, A. M. Y. Crescimento inicial e composição bromatológica de plantas de pornuncia adubadas com fósforo e inoculadas com fungos micorrízicos arbusculares. Revista Brasileira de Saúde e Produção Animal, Salvador, v. 17, n. 4, p. 561571, 2016. DOI: 10.1590/s1519-99402016000400001

NATIONAL RESEARCH COUNCIL - NRC. Nutrient requirements of small ruminants. Washington: National Academy Press, 2007. 362 p.

NGUYEN, T. T. G.; WANAPAT, M.; PHESATCHA, K.; KANG, S. Effect of inclusion of different levels of Leucaena silage on rumen microbial population and microbial protein synthesis in dairy steers fed on rice straw. Asian-Australasian Journal of Animal Sciences, Bethesda, v. 30, n. 2, p. 181-186, 2017. DOI: 10.5713/ ajas. 15.0948

OLADOSU, Y.; RAFII, M. Y.; ABDULLAH, N.; MAGAJI, U.; HUSSIN, G.; RAMLI, A.; MIAH, G. Fermentation quality and additives: A case of rice straw silage. BioMed Research International, London, v. 2016, n. 1, p. 1-14, 2016. DOI: 10.1155/2016/7985167

RÊGO, A. C.; OLIVEIRA, M. D. S.; SIGNORETTI, R. D. Importância do tamanho de partícula e do uso de inoculante bacteriano em silagens. Revista Colombiana de Ciência Animal, Sincelejo, v. 7, n. 1, p. 88-99, 2015. Disponível em: https://revistas.unisucre.edu.co/index. $\mathrm{php} / \mathrm{recia} / \mathrm{article} / \mathrm{download} / 428 / 474 /$. Acesso em: 08 jan. 2018.

SANTOS, K. C.; MAGALHÃES, A. L. R.; SILVA, D. K. A.; ARAÚJO, G. G. L.; FAGUNDES, G. M.; YBARRA, N. G.; ABDALLAF, A. L. Nutritional potential of forage species found in Brazilian Semiarid region. Livestock Science, Elsevier, v. 195, n. 1, p. 118-124, 2017. DOI: 10.1016/j.livsci.2016.12.002

SILVA, D. J.; QUEIROZ, A. C. Análise de alimentos: métodos químicos e biológicos. Viçosa, MG: Editora UFV, 2002. $235 \mathrm{p}$.

SILVA, T. M. A.; ARAÚJO, G. G. L. A.; OLIVEIRA, R. L. B.; DANTAS, F. R. B.; BAGALDO, A. R. C.; MENEZES, D. R. B.; GARCEZ NETO, A. F. C.; FERREIRA, G. D. G. Degradabilidade ruminal e valor nutritivo da maniçoba ensilada com níveis do resíduo vitivinícola. Archivos de Zootecnia, Córdoba, v. 60, n. 229, p. 93-103, 2011. DOI: $10.4321 / \mathrm{S} 0004-05922011000100011$

SNIFFEN, C. J.; O'CONNOR, D. J.; VAN SOEST, P. J.; SNIFFEN, C. J.; O'CONNOR, D. J.; VAN SOEST, P. J.; FOX, D. G.; RUSSELL, J. B. A net carbohydrate and protein system for evaluating cattle diets: carbohydrate and protein availability. Journal of Animal Science, Champaign, v. 70 , n. 11, p. $3562-3577$, 1992. DOI: $10.2527 / 1992.70113562 \mathrm{x}$

SOUZA, L. C.; ZAMBOM, M. A.; GUNDT, S.; PASQUALOTTO, M.; SANTOS, G. T.; CASTAGNARA, D. D.; KAZAMA, D. C. S. Composição química e degradabilidade ruminal de forragens e subprodutos agroindustriais na região oeste do Paraná. Bioscience Journal, Uberlândia, v. 31, n. 1, p. 171-180, 2015. DOI: 10.14393/BJ-v31n1a2015-17252

STATISTICAL ANALYSIS SYSTEM - SAS. SAS system: SAS/STAT. version 9.2 (software), Cary: SAS Institute, 2011.

TILLEY, J. M. A.; TERRY, R. A. A two-stage technique for the in vitro digestion of forage crops. Grass and 
Forage Science, Oxford, v. 18, n. 2, p. 104-111, 1963. DOI: $10.1111 / \mathrm{j} .1365-2494.1963 . t b 00335 . x$

TOLENTINO, D. C.; RODRIGUES, J. A. S.; PIRES, D. A. A.; VERIATO, F. T.; LIMA, L. O. B.; MOURA, M. M. A. The quality of silage of different sorghum genotypes. Acta Scientiarum. Animal Sciences, Maringá, v. 38, n. 2 , p. $143-149$, 2016. DOI: 10.4025 /actascianimsci. v38i2. 29030

TOMICH, T. R.; PEREIRA, L. G. R.; GONÇALVES, L. C.; TOMICH, R. G. P.; BORGES, I. Características químicas para avaliação do processo fermentativo de silagens: uma proposta para qualificação da fermentação. Corumbá: EMBRAPA Pantanal, 2003. 20 p. (Documentos, 57).
VAN SOEST, P. J.; ROBERTSON, J. B.; LEWIS, B. A. Methods for dietary fiber, neutral detergent fiber, and nonstarch polyssacharides in relation to animal nutrition. Journal of Dairy Science, Champaign, v. 74, n. 10 p. 35833597, 1991. DOI: 10.3168/jds.S0022-0302(91)78551-2

VIEIRA, P. F. Efeito do formaldeído na proteção de proteínas e lipídeos em rações. 1980. Tese (Doutorado em Zootecnia) - Universidade Federal de Viçosa, Viçosa, MG.

WICHELNS, D. Achieving water and food security in 2050: outlook, policies, and investments. Agriculture, Basel, v. 5, n. 2, p. 188-220, 2015. DOI:10.3390/ agriculture 5020188 